\title{
COVID-19 Pandemic and Mental Health Problems among Healthcare Professionals: A Review
}

Jayanthi P

\begin{abstract}
The prevalence of novel coronavirus disease (COVID-19) is increasing day by day locally, nationally, and internationally. The common mental health problems experienced by the healthcare workers (HCWs) are anxiety, stress, depression, and insomnia. In all, 59\% of HCWs are experiencing moderate to severe perceived stress. Symptoms of depression and anxiety were found in one of five healthcare professionals. The occurrence of anxiety and depression was high among female HCWs and nursing staff. The prevalence of anxiety for doctors was $21.73 \%$ and nurses was $25.80 \%$. The prevalence rate of depression for nurses was $29.65 \%$ and for the doctors was $24.5 \%$. Four in $10 \mathrm{HCWs}$ are experiencing sleeping difficulties and/or insomnia. Estimated insomnia prevalence rate was 38.9\%. The possible solutions to overcome the mental health problems among HCWs are increased manpower, community awareness, adequate knowledge about virus prevention and transmission, social isolation, and adequate supply of personal protective equipments (PPEs).
\end{abstract}

Keywords: Anxiety, Coronavirus, COVID-19, Depression, Healthcare professionals, Insomnia, Mental health, Stress.

Pondicherry Journal of Nursing (2021): 10.5005/jp-journals-10084-12160

\section{INTRODUCTION}

The prevalence of novel coronavirus disease (COVID-19) is increasing day by day locally, nationally, and internationally. The COVID-19 pandemic is a major health crisis affecting several nations, with over $6,194,533$ cases and 376,320 confirmed deaths reported to date (June 02, 2020). Throughout the world, around 216 countries developed this infectious disease, and healthcare workers (HCWs) are the frontline warriors fight against this condition and actively participating in the screening and treatment process. ${ }^{1}$

\section{Objectives}

The aim of this review is to better understand the research findings on mental health issues experienced by healthcare workers (HCW) due to COVID-19 pandemic.

\section{Literature Search}

The following databases were utilized for literature search such as PubMed, Google Scholar, Cochrane Library, Embase. Psychological issues or stress or anxiety or depression or mental health problems or psychiatric issues and COVID-19, corona, novel corona virus and $\mathrm{HCW}$, or doctors, or medical staff, or nurses, or healthcare professionals were the key terms used for the literature search.

Articles published in the last 5 months (January 2020-May 2020) were retrieved. Author reviewed the articles in the form of letter to the editor, original research article, review, commentary, and correspondence. A total of 14 studies were included in the review.

\section{Overview}

The holistic health of the healthcare workforce is the heart of every well-functioning health system. Medical healthcare providers are experiencing increased workload and increased total health expenditures due to COVID-19 pandemic. Risk of exposure is high among HCWs who are directly involved in the care of patient with COVID-19 than others. The common mental health problems
Department of Mental Health Nursing, Sri Sathya Sai College of Nursing, Chennai, Tamil Nadu, India

Corresponding Author: Jayanthi P, Department of Mental Health Nursing, Sri Sathya Sai College of Nursing, Chennai, Tamil Nadu, India, Phone: +91 7358614997, e-mail: jayanthiarul2011@gmail.com

How to cite this article: P Jayanthi. COVID-19 Pandemic and Mental Health Problems among Healthcare Professionals: A Review. Pon J Nurs 2021;14(1):17-20.

Source of support: Nil

Conflict of interest: None

experienced by the HCWs are anxiety, stress, depression, and insomnia. The pandemic burden of COVID-19 illness could lead to caregiver burnout. Lengthy working hours, inadequate personal protective equipment, media news, fatigue, lack of support system, insomnia, and the risk of getting infection for themselves and their family members are the major causes of psychological distress among HCWs. Increased infection rate and death among medical staff is another important reason for mental health problems among HCW. HCWs are experiencing frustration, helplessness, adjustment problems, stigma, fear of discrimination in the medical staff due to the sudden role reversal from HCW to a patient ${ }^{2-5}$ (Table 1).

\section{Perceived Stress}

In all, 59\% of healthcare workers are experiencing moderate to severe perceived stress. ${ }^{6}$ Perceived risk of infection to themselves and their family members, increasing patient mortality, lack of personal protective equipment, degree of contact with confirmed or suspected cases, multiple needs of the patients, stigma are the factors associated with stress. ${ }^{7}$

\section{AnXiety}

Symptoms of depression and anxiety were found in one out of five healthcare professionals. ${ }^{6}$ The occurrence of anxiety and 
Table 1: Studies related to COVID-19 pandemic and mental health problems among HCW

\begin{tabular}{|c|c|c|c|c|c|}
\hline Author and Year & Study design & $\begin{array}{l}\text { Sample and sample } \\
\text { size }\end{array}$ & Setting & Instrument used & Findings \\
\hline Cai et al. (2020) & Cross-sectional study & $\begin{array}{l}534 \text { frontline medical } \\
\text { staff } \\
\text { Nurses-248 } \\
\text { Doctors-233 } \\
\text { Medical } \\
\text { technicians-48 } \\
\text { Hospital staff-5 }\end{array}$ & Hubei, China & $\begin{array}{l}\text { Questionnaire by Lee } \\
\text { et al., } 2005\end{array}$ & $\begin{array}{l}\text { Medical staffs were having } \\
\text { emotional stress and } \\
\text { anxiety }\end{array}$ \\
\hline Kang et al. (2020) & Cross-sectional study & $\begin{array}{l}994 \text { medical and } \\
\text { nursing staff }\end{array}$ & Wuhan & $\begin{array}{l}\text { Patient health } \\
\text { questionnaire-9, } \\
\text { generalized anxiety } \\
\text { disorder, insomnia sever- } \\
\text { ity index and the impact } \\
\text { of event scale-revised }\end{array}$ & $\begin{array}{l}36.9 \% \text { had subthreshold } \\
\text { mental health distur- } \\
\text { bances, } 34.4 \% \text { had mild } \\
\text { disturbances, } 22.4 \% \text { had } \\
\text { moderate disturbances, } \\
\text { and } 6.2 \% \text { had severe dis- } \\
\text { turbances }\end{array}$ \\
\hline Lai et al. (2020) & $\begin{array}{l}\text { Cross-sectional region } \\
\text { stratified study }\end{array}$ & $\begin{array}{l}\text { 1,257 healthcare } \\
\text { workers } \\
\text { Nurses-764 } \\
\text { Physicians-493 }\end{array}$ & $\begin{array}{l}34 \text { hospitals in } \\
\text { China }\end{array}$ & $\begin{array}{l}\text { 9-item patient health } \\
\text { questionnaire, the } \\
\text { 7-item generalized } \\
\text { anxiety disorder scale, } \\
\text { the 7-item insomnia } \\
\text { severity index, and the } \\
\text { 22-item impact of event } \\
\text { scale-revised }\end{array}$ & $\begin{array}{l}\text { Depression-50.4\%, anxie- } \\
\text { ty-44.6\%, insomnia-34.0\%, } \\
\text { and distress-71.5\%. }\end{array}$ \\
\hline Xiao et al. (2020) & $\begin{array}{l}\text { Cross-sectional obser- } \\
\text { vational study }\end{array}$ & $\begin{array}{l}180 \text { medical staff } \\
\text { (Doctors or nurses) }\end{array}$ & Wuhan & $\begin{array}{l}\text { Self-rating anxiety scale, } \\
\text { the general self-efficacy } \\
\text { scale, the Stanford } \\
\text { acute stress reaction } \\
\text { questionnaire, the } \\
\text { Pittsburgh sleep quality } \\
\text { index, and the social } \\
\text { support rate scale }\end{array}$ & $\begin{array}{l}\text { Levels of social support } \\
\text { were significantly associ- } \\
\text { ated with self-efficacy and } \\
\text { sleep quality and nega- } \\
\text { tively associated with the } \\
\text { degree of anxiety and } \\
\text { stress. }\end{array}$ \\
\hline Liu et al. (2020) & Cross-sectional study & $\begin{array}{l}512 \text { medical staff } \\
\text { doctors, nurses } \\
\text { and administrative } \\
\text { workers }\end{array}$ & Hubei, China & $\begin{array}{l}\text { Zung self-rating Anxiety } \\
\text { scale }\end{array}$ & $\begin{array}{l}\text { Prevalence of } \\
\text { anxiety-12.5\% } \\
\text { Mild-10.35\% } \\
\text { Moderate- } 1.36 \% \\
\text { Severe-0.78\% }\end{array}$ \\
\hline Liang et al. (2020) & Cross-sectional study & $\begin{array}{l}59 \text { doctors and } \\
\text { nurses from COVID- } \\
\text { 19-associated depart- } \\
\text { ments and others }\end{array}$ & $\begin{array}{l}\text { Guangdong } \\
\text { Province }\end{array}$ & $\begin{array}{l}\text { Zung's self-rating } \\
\text { depression scale (SDS), } \\
\text { Zung's self-rating anxiety } \\
\text { scale (SAS). }\end{array}$ & $\begin{array}{l}\text { Several staff were experi- } \\
\text { encing clinically significant } \\
\text { depressisve symptoms }\end{array}$ \\
\hline $\begin{array}{l}\text { Mohindra et al. } \\
\text { (2020) }\end{array}$ & Qualitative analysis & $\begin{array}{l}\text { Frontline health- } \\
\text { care providers (HP) } \\
\text { involved in the } \\
\text { care of patients } \\
\text { with COVID-19 or } \\
\text { suspected COVID-19 } \\
\text { Sample size-Not } \\
\text { specified }\end{array}$ & $\begin{array}{l}\text { Tertiary hospital } \\
\text { in North India }\end{array}$ & Interviews with HP & $\begin{array}{l}\text { The main themes identi- } \\
\text { fied were: } \\
\text { (1) Positive motivational } \\
\text { factors } \\
\text { (a) Intellectual } \\
\text { (b) Emotional } \\
\text { (2) Negatives, frustrations } \\
\text { associated with patient } \\
\text { care } \\
\text { (3) Personal fears } \\
\text { and annoyances } \\
\text { experienced by doctors }\end{array}$ \\
\hline \multirow[t]{3}{*}{ Du et al. (2020) } & \multirow[t]{3}{*}{ Cross-sectional survey } & \multirow[t]{3}{*}{$\begin{array}{l}134 \text { Frontline } \\
\text { healthcare workers }\end{array}$} & \multirow[t]{3}{*}{$\begin{array}{l}\text { Four hospitals in } \\
\text { Wuhan. }\end{array}$} & $\begin{array}{l}\text { Beck depression Inven- } \\
\text { tory II }\end{array}$ & Depression-12.7\% \\
\hline & & & & Beck Anxiety Inventory & Anxiety-20.1\% \\
\hline & & & & Perceived Stress Scale & $\begin{array}{l}\text { Moderate to severe } \\
\text { perceived stress-59\% }\end{array}$ \\
\hline
\end{tabular}




\begin{tabular}{|c|c|c|c|c|c|}
\hline Author and Year & Study design & $\begin{array}{l}\text { Sample and sample } \\
\text { size }\end{array}$ & Setting & Instrument used & Findings \\
\hline Guo J et al. (2020) & $\begin{array}{l}\text { A systematic review } \\
\text { and meta-analysis }\end{array}$ & $\begin{array}{l}33,062 \text { Healthcare } \\
\text { workers }\end{array}$ & $\begin{array}{l}\text { Thirteen studies } \\
\text { from China, Wu- } \\
\text { han, Singapore }\end{array}$ & SASSDS & $\begin{array}{l}\text { Depression-22.8\%, } \\
\text { Anxiety-23.2\% } \\
\text { Insomnia-38.9\% }\end{array}$ \\
\hline Lu et al. (2020) & Cross-sectional survey & $\begin{array}{l}\text { 2,299 participants } \\
\text { Medical staff-2042 } \\
\text { Administrative } \\
\text { staff-257 }\end{array}$ & $\begin{array}{l}\text { Fujian provincial } \\
\text { hospital }\end{array}$ & $\begin{array}{l}\text { Numeric rating scale } \\
\text { (NRS) on fear, hamilton } \\
\text { anxiety scale (HAMA), } \\
\text { and Hamilton depres- } \\
\text { sion scale (HAMD) }\end{array}$ & $\begin{array}{l}\text { Medical staffs were } 1.4 \\
\text { times more likely to } \\
\text { feel fear, twice more } \\
\text { likely to suffer anxiety and } \\
\text { depression. }\end{array}$ \\
\hline Qi J et al. (2020) & Cross-sectional study & $\begin{array}{l}\text { 1,306 participants } \\
\text { Frontline medical } \\
\text { workers-801 } \\
\text { Non-FMW-505 }\end{array}$ & $\begin{array}{l}\text { Hubei Province, } \\
\text { China }\end{array}$ & $\begin{array}{l}\text { Pittsburgh sleep quality } \\
\text { index (PSQI), Athens } \\
\text { insomnia scale (AIS), and } \\
\text { visual analogue scale } \\
\text { (VAS) }\end{array}$ & $\begin{array}{l}\text { Frontline medical } \\
\text { workers (FMW) had } \\
\text { higher prevalence of sleep } \\
\text { disturbances and worse } \\
\text { sleep quality than non- } \\
\text { FMW. }\end{array}$ \\
\hline Tan et al. (2020) & Cross-sectional study & $\begin{array}{l}470 \text { participants } \\
\text { Medical healthcare } \\
\text { personnel-296 } \\
\text { Non-medical health- } \\
\text { care personnel-174 }\end{array}$ & $\begin{array}{l}2 \text { major tertiary } \\
\text { institutions in } \\
\text { Singapore }\end{array}$ & $\begin{array}{l}\text { Depression, anxiety, and } \\
\text { stress scales (DASS-21) } \\
\text { and the impact of events } \\
\text { scale-revised (IES-R) } \\
\text { instrument }\end{array}$ & $\begin{array}{l}\text { Medical healthcare } \\
\text { personnel } \\
\text { Depression-8.1\% } \\
\text { Anxiety-10.8\% } \\
\text { Stress-6.4\% } \\
\text { PTSD-5.7\% } \\
\text { Nonmedical healthcare } \\
\text { personnel } \\
\text { Depression-10.3\% } \\
\text { Anxiety-20.7\% } \\
\text { Stress-6.9\% } \\
\text { PTSD-10.9\% }\end{array}$ \\
\hline $\begin{array}{l}\text { Zhang et al. } \\
(2020)\end{array}$ & Cross-sectional study & $\begin{array}{l}2,182 \text { participants } \\
\text { nonmedical health } \\
\text { workers-1,255 } \\
\text { Medical health } \\
\text { workers-927 }\end{array}$ & China & $\begin{array}{l}\text { Insomnia severity index } \\
\text { (ISI), the symptom check } \\
\text { list-revised (SCL-90-R), } \\
\text { and the patient health } \\
\text { questionnaire-4 (PHQ-4) }\end{array}$ & $\begin{array}{l}\text { Compared with non- } \\
\text { medical health workers, } \\
\text { medical health workers } \\
\text { had a higher prevalence of } \\
\text { insomnia ( } 38.4 \text { vs } 30.5 \%) \\
\text { anxiety ( } 13.0 \text { vs } 8.5 \%), \\
\text { depression ( } 12.2 \text { vs } 9.5 \%), \\
\text { somatization ( } 1.6 \text { vs } 0.4 \%) \\
\text { and obsessive-compulsive } \\
\text { symptoms ( } 5.3 \text { vs } 2.2 \% \text { ). }\end{array}$ \\
\hline Zhu et al. (2020) & Cross-sectional survey & 5,062 Health workers & Wuhan, China & $\begin{array}{l}\text { Impact of event scale- } \\
\text { revised (IES-R), patient } \\
\text { health questionnaire-9 } \\
\text { (PHQ-9), and generalized } \\
\text { anxiety disorder 7-item } \\
\text { (GAD-7) }\end{array}$ & $\begin{array}{l}\text { Stress-29.8\% } \\
\text { Depression-13.5\% } \\
\text { Anxiety-24.1\% }\end{array}$ \\
\hline
\end{tabular}

depression were high among female HCWs and nursing staff. The pooled prevalence rate of anxiety was $20.92 \%$ for males and $29.06 \%$ for females. The prevalence of anxiety for doctors was $21.73 \%$ and nurses was $25.80 \%$. The pooled prevalence rate for mild anxiety was $17.93 \%$ and severe anxiety was $6.88 \% .^{8-14}$

\section{DePRESSION}

The pooled depression prevalence rate for men was $20.34 \%$, and women was $26.87 \% .^{6,8-11}$ The prevalence rate of depression for nurses was $29.65 \%$, whereas for the doctors it was $24.5 \% .{ }^{6,8-11}$ Regarding the severity of the depression, pooled prevalence rate for mild depression was $24.60 \%$ and moderate/severe depression was $16.18 \%{ }^{6,12,13,15}$

\section{INSOMNIA}

Four in $10 \mathrm{HCW}$ are experiencing sleeping difficulties and/or insomnia. ${ }^{5}$ Estimated insomnia prevalence rate was $38.9 \% .{ }^{16,17}$

\section{Discussion}

The occurrence of mental health problems, such as anxiety and depression among HCWs, differed based on the gender, handling 
confirmed/suspected cases and occupation. Affective symptoms were high among female HCPs and nurses when compared to male and medical staff, respectively. Rate of anxiety was high among $\mathrm{HCWs}$ who were treated confirmed cases, quarantined, and handled suspect cases. The risk of exposure is very high among nurses who are spending more time with patients, collecting sputum, and providing direct care. $^{18}$

Nurses are witnessing the infection of coworkers and family members, protective measures, and medical violence which increases their stress and anxiety. Support system plays a major role in mediating the mental health problems. Increased social support enhances the self-efficacy and sleep quality of the HCWs, whereas decreased social support lead to anxiety and stress among them. ${ }^{3,4}$

HCW's attention, understanding, and decision-making ability are affected by their mental health problems which hinder the fight against 2019 novel corona virus and also affect their overall wellbeing. ${ }^{19}$ Thus, protection of HCW's mental health is very important for control of the COVID-19 pandemic and their own long-term health. Hospital authorities' support, adequate supplies, and provision of facilities are needed to retain and encourage HCWs in future epidemics. Research has identified five things required for the HCWs from their employer are hear me, protect me, prepare me, support me, and care for me during the COVID-19 pandemic situation. $^{20}$

\section{Conclusion}

The increasing burden of COVID-19 pandemic leads to mental health problems among $\mathrm{HCWs}$. In order to maintain the overall well-being of the HCWs and volunteers, time-limited and culturally sensitive mental health interventions can be taught to them on day-to-day basis. Multidisciplinary mental health teams at regional and national level have to be set up by the health authorities in order to deal with mental health issues and provide constant and consistent psychological support to both patients and HCW. HCWs who are having direct contact with COVID-19 patients can undergo regular screening in order to evaluate stress, anxiety, depression and PTSD in them. The possible solutions to overcome the mental health problems among HCWs are increased manpower, community awareness, adequate knowledge about virus prevention and transmission, social isolation, and adequate supply of personal protective equipments.

\section{References}

1. World Health Organization. Novel coronavirus (2019-nCoV) situation reports. Geneva: World Health Organization; 2020.

2. Rana W, Mukhtar S, Mukhtar S. Mental health of medical workers in Pakistan during the pandemic COVID-19 outbreak. Asian J Psychiat 2020;51:102080. DOI: 10.1016/j.ajp.2020.102080.

3. Rajkumar. COVID-19 and mental health: a review of the existing literature. Asian J Psychiatr 2020;52:102066. DOI: 10.1016/j. ajp.2020.102066.

4. Spoorthy MS, Pratapa SK, Mahant S. Mental health problems faced by healthcare workers due to the COVID-19 pandemic- a review. Asian J Psychiatr 2020;51:102119. DOI: 10.1016/j.ajp.2020.102119.
5. Mohindra R, Ravali R, Suri V, Bhalla A, Singh SM. Issues relevant to mental health promotion in frontline health care providers managing quarantined/isolated COVID19 patients. Asian J Psychia 2020;51:102084. DOI: 10.1016/j.ajp.2020.10208451.

6. Du J, Dong L, Wang T, Yuan C, Fu R, Zhang L, et al. Psychological symptoms among frontline healthcare workers during COVID-19 outbreak in Wuhan. Gen Hosp Psychiatry 2020. S0163-8343(20)300451 10.1016/j.genhosppsych.2020.03.011.

7. Cai H, Tu B, Ma J, Chen L, Fu L, Jiang Y, et al. Psychological impact and coping strategies of frontline medical staff in hunan between January and March 2020 during the outbreak of coronavirus disease 2019 (COVID19) in Hubei, China. Med Sci Monit 2020. 26. DOI: 10.12659/ MSM.924171.

8. Guo J, Liao L, Wang B, Li X, Guo L, Tong Z, et al. Psychological effects of COVID-19 on hospital staff: a national cross-sectional survey of China Mainland. SSRN Electron J 2020. DOI: 10.2139/ssrn.3550050.

9. Huang $Y$, Zhao N. Generalized anxiety disorder, depressive symptoms and sleep quality during COVID-19 epidemic in China: a web-based cross-sectional survey. medRxiv 2020. DOI: 10.1101/2020.02.19.20025395.

10. Lai J, Ma S, Wang Y, Cai Z, Hu J, Wei N, et al. Factors associated with mental health outcomes among health care workers exposed to coronavirus disease 2019. AMA Netw Open 2020;3(3):e203976. DOI: 10.1001/jamanetworkopen.2020.3976.

11. Liu C, Yang Y, Zhang XM, Xu X, Dou Q-L, Zhang W-W. The prevalence and influencing factors for anxiety in medical workers fighting COVID-19 in China: a cross-sectional survey. medRxiv 2020. DOI: 10.1101/2020.03.05.20032003.

12. Liu Z, Han B, Jiang R, Huang Y, Ma C, Wen J, et al. Mental health status of doctors and nurses during COVID-19 epidemic in China. SSRN Electron J 2020. DOI: 10.2139/ssrn.3551329.

13. Lu W, Wang H, Lin Y, Li L. Psychological status of medical workforce during the COVID-19 pandemic: a cross-sectional study. Psychiatry Res 2020;288:112936. DOI: 10.1016/j.psychres.2020.112936.

14. Qi R, Chen W, Liu S, Thompson PM, Zhang LJ, Xia F, et al. The Evaluation of sleep disturbances for chinese frontline medical workers under the outbreak of COVID-19. medRxiv 2020. DOI: 10.1101/2020.03.06.20031278

15. Tan BYQ, Chew NWS, Lee GKH, Jing M, Goh Y, Yeo L, et al. Psychological impact of the COVID-19 pandemic on health care workers in Singapore. Ann Intern Med 2020(4). DOI: 10.7326/M20-1083.

16. Zhang C, Yang L, Liu S, Ma S, Wang Y, Cai Z, et al. Survey of insomnia and related social psychological factors among medical staff involved in the 2019 novel coronavirus disease outbreak. Front Psychiatry 2020;11:306. DOI: 10.3389/fpsyt.2020.00306.

17. Pappa S, Ntella V, Giannakas T, Giannakoulis VG, Papoutsi E, Katsaounou P. Prevalence of depression, anxiety, and insomnia among healthcare workers during the COVID-19 pandemic: a systematic review and meta-analysis. Brain Behav Immun 2020;88:901-907. DOI: 10.1016/j.bbi.2020.05.026.

18. Zhu Z, Xu S, Wang H, Liu Z, Wu J, Li G, et al. COVID-19 in Wuhan: immediate psychological impact on 5062 health workers. medRxiv 2020. DOI: $10.1101 / 2020.02 .20 .20025338$

19. Kang L, Li Y, Hu S, Chen M, Yang C, Yang BX. The mental health of medical workers in Wuhan, China dealing with the 2019 novel coronavirus. Lancet Psychiatry 2020;7(3):e14. DOI: 10.1016/S22150366(20)30047-X.

20. Shanafelt T, Ripp J, Trockel M. Understanding and addressing sources of anxiety among health care professionals during the COVID-19 pandemic. JAMA 2020;323(21):2133-2134. DOI: 10.1001/ jama.2020.58932020. 